\title{
Multivariate statistic and time series analyses of grain-size data in quaternary sediments of Lake El'gygytgyn, NE Russia
}

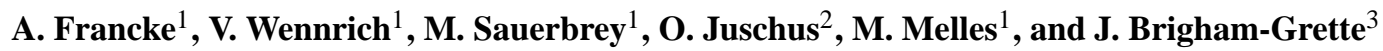 \\ ${ }^{1}$ University of Cologne, Institute for Geology and Mineralogy, Cologne, Germany \\ ${ }^{2}$ Eberswalde University for Sustainable Development, Eberswalde, Germany \\ ${ }^{3}$ University of Massachusetts, Department of Geosciences, Amherst, USA \\ Correspondence to: A. Francke (alexander.francke@uni-koeln.de)
}

Received: 14 December 2012 - Published in Clim. Past Discuss.: 14 January 2013

Revised: 20 September 2013 - Accepted: 3 October 2013 - Published: 5 November 2013

\begin{abstract}
Lake El'gygytgyn, located in the Far East Russian Arctic, was formed by a meteorite impact about $3.58 \mathrm{Ma}$ ago. In 2009, the International Continental Scientific Drilling Program (ICDP) at Lake El'gygytgyn obtained a continuous sediment sequence of the lacustrine deposits and the upper part of the impact breccia. Here, we present grain-size data of the past 2.6 Ma. General downcore grain-size variations yield coarser sediments during warm periods and finer ones during cold periods. According to principal component analysis (PCA), the climate-dependent variations in grainsize distributions mainly occur in the coarse silt and very fine silt fraction. During interglacial periods, accumulation of coarser material in the lake center is caused by redistribution of clastic material by a wind-induced current pattern during the ice-free period. Sediment supply to the lake is triggered by the thickness of the active layer in the catchment and the availability of water as a transport medium. During glacial periods, sedimentation at Lake El'gygytgyn is hampered by the occurrence of a perennial ice cover, with sedimentation being restricted to seasonal moats and vertical conduits through the ice. Thus, the summer temperature predominantly triggers transport of coarse material into the lake center. Time series analysis that was carried out to gain insight into the frequency of the grain-size data showed variations predominately on $98.5,40.6$, and $22.9 \mathrm{kyr}$ oscillations, which correspond to Milankovitch's eccentricity, obliquity and precession bands. Variations in the relative power of these three oscillation bands during the Quaternary suggest that sedimentation processes at Lake El'gygytgyn are dominated by environmental variations caused by global
\end{abstract}

glacial-interglacial variations (eccentricity, obliquity), and local insolation forcing and/or latitudinal teleconnections (precession), respectively.

\section{Introduction}

The polar regions are known to play a crucial but not yet well understood role within the global climate system (Washington and Meehl, 1996; Johannessen et al., 2004), influencing both the oceanic and the atmospheric circulation. The recent global warming trend has been, and is predicted to be, most pronounced in the Arctic (ACIA, 2004; Serreze and Francis, 2006). However, rather little is known about the natural and environmental variability on geological timescales. Our current knowledge on the Cenozoic climate evolution of the Arctic has long been based on sparse, often discontinuous marine and terrestrial paleorecords of the Arctic Ocean and adjacent landmasses (Thiede et al., 1998; Moran et al., 2006; Axford et al., 2009; Pienitz et al., 2009; Zech et al., 2011).

The first continuous Pliocene-Pleistocene sediment record in the terrestrial Arctic was recovered in 2009 during a deep drilling campaign of the International Continental Scientific Drilling Program (ICDP) at Lake El'gygytgyn in the Far East Russian Artic (Fig. 1; Melles et al., 2011). Pilot studies on Lake El'gygytgyn sediments covering the last 2-3 glacial-interglacial cycles had already demonstrated the usability of this archive for paleoclimate reconstructions (e.g. Brigham-Grette et al., 2007; Melles et al., 2007; Niessen et al., 2007). Initial results from the upper part 
of the $318 \mathrm{~m}$-long sediment record in central parts of the lake (ICDP site 5011-1) provided first details of Quaternary history, focusing on interglacial variability during the past 2.8 Myr (Melles et al., 2012).

Here, we present new results of granulometric analyses on ICDP core 5011-1 throughout the past 2.6 Myr. Grain-size data have extensively been used before as a paleoenvironmental and -climatological proxy on long terrestrial and lacustrine sedimentary records, including those from the Chinese Loess Plateau (e.g. An et al., 1991; Sun and Huang, 2006; Sun et al., 2006) and from lakes Baikal (Kashiwaya et al., 1998, 2001) and Biwa (Kashiwaya et al., 1987). At Lake El'gygytgyn, previous studies of grain-size variations are widely restricted to the sediments formed during the past $65 \mathrm{ka}$ (Asikainen et al., 2007). During this period, particlesize variations were predominantly controlled by the regional climatic settings and their impacts on the physical properties in the lake and its catchment. Our grain-size investigations on ICDP core 5011-1 extend the results from this early research to the entire Quaternary. Furthermore, we incorporated more recent findings on the modern climatological, hydrological, and sedimentological settings (Fedorov et al., 2013; Nolan et al., 2013; Wennrich et al., 2013a). To better understand the sedimentological processes operating in Lake El'gygytgyn, we used principal component analysis (PCA) to detect dominating variations in the grain-size distributions, and we employed time series analysis to reveal oscillations in the granulometric data and their relative dominance over time.

\section{Site information}

Lake El'gygytgyn is located in the Far East Russian Arctic, in the central part of the Chukchi Peninsula $\left(67^{\circ} 30^{\prime} \mathrm{N}\right.$, $172^{\circ} 05^{\prime}$ E, $492 \mathrm{~m}$ a.s.l.; Fig. 1). It is formed within a meteorite impact crater (e.g. Dietz and McHone, 1977; Gurov et al., 1979) dated to about 3.58 Ma (Layer, 2000). The lake has a nearly circular shape with a diameter of about $12 \mathrm{~km}$ and a depth of about $175 \mathrm{~m}$ (Nolan and Brigham-Grette, 2007), whereas the catchment confined by the crater rim measures about $18 \mathrm{~km}$ in diameter (corresponding to $293 \mathrm{~km}^{2}$ ). Today, the lake is not located in the center of the crater but slightly displaced to the southeast, resulting in an asymmetric catchment area (Fig. 1).

The El'gygytgyn crater region is part of the central Chukchi sector of the Okhotsk-Chukchi volcanic belt (Gurov and Gurova, 1979; Gurov et al., 2007). It is dominated by acid volcanic rocks, ignimbrites and tuffaceous clastic rocks of the late Cretaceous (e.g. Gurov et al., 2007; Stone et al., 2009). The lake is surrounded by continuous permafrost, whose onset can presumably be traced back to the late Pliocene (Glushkova and Smirnov, 2007), and which is assumed to have a thickness of about $330-360 \mathrm{~m}$ with an unfrozen talik underneath the lake today (Mottaghy et al., 2013). The recent geomorphologic shape of the lake
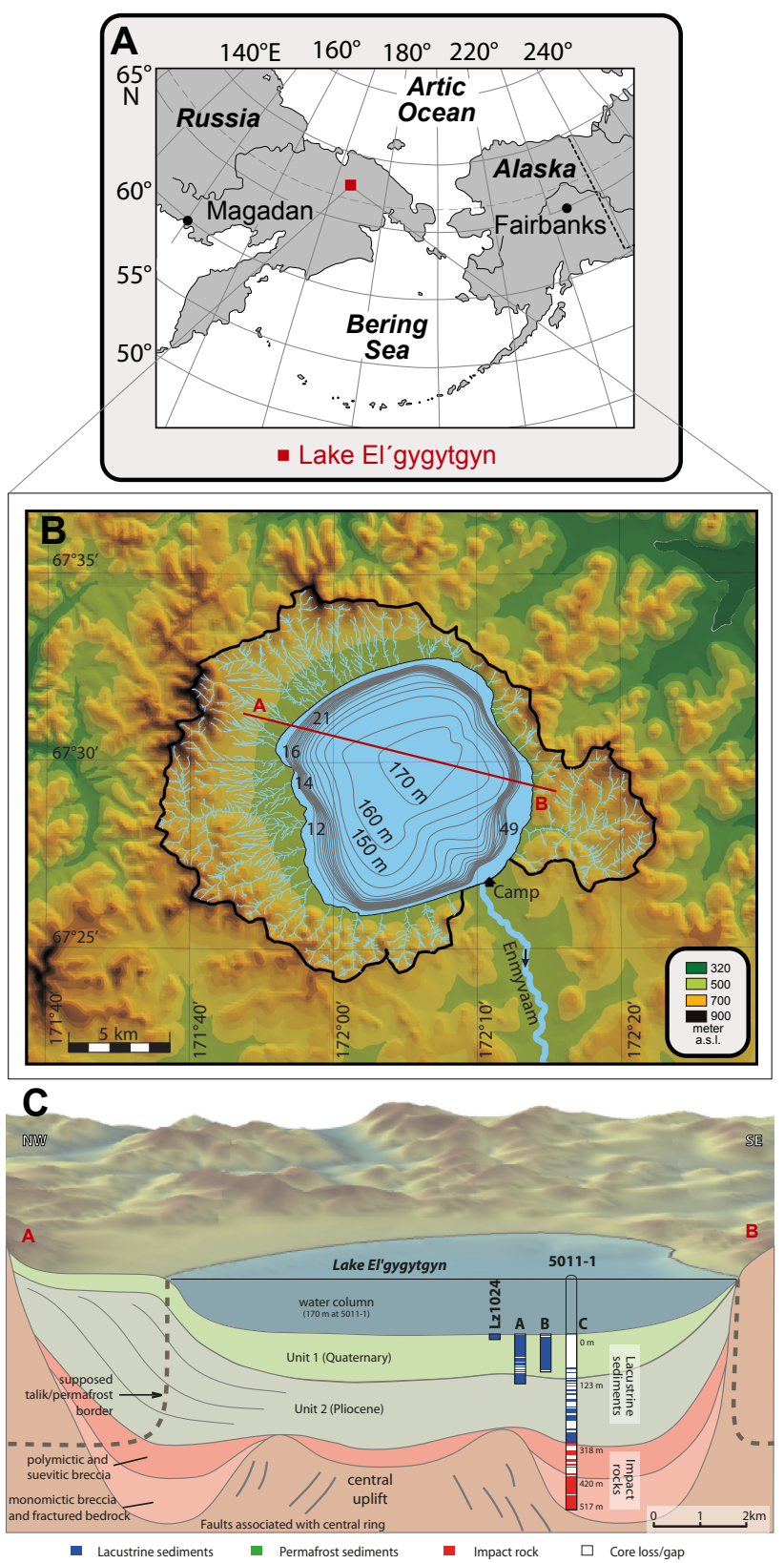

Fig. 1. (A) Location of Lake El'gygytgyn in the Far East Russian Artic; (B) bathymetric map of the lake and topographic map of the catchment area, including the approximately 50 inlet streams and the Enmyvaam River outlet (Fedorov and Kupolov, 2005); red line: profile A to B. (C) Schematic profile A to B with the locations of the pilot core Lz 1024 and the three holes (A, B and C) at ICDP site 5011-1 with the Pliocene-Pleistocene boundary penetrated at approximately $123 \mathrm{~m}$, and the transition to the impact breccia at $318 \mathrm{~m}$ below lake floor (modified after Melles et al., 2011).

catchment is predominantly affected by permafrost processes such as solifluction and cryogenic weathering (Glushkova and Smirnov, 2007). In addition, distinct lake-level variations during the Middle Pleistocene to Holocene modified the geomorphic shape of the area and resulted in various 
accumulative and erosional terraces at 35-40, 9-11 and 2.5$3.0 \mathrm{~m}$ above as well as $10 \mathrm{~m}$ below the modern lake level (Glushkova and Smirnov, 2007; Juschus et al., 2011).

The catchment of Lake El'gygytgyn is dissected by approximately 50 ephemeral inlet streams (see Fig. 1; Nolan and Brigham-Grette, 2007), which deliver sediment in the order of ca. $350 \mathrm{t} \mathrm{yr}^{-1}$ into the lake (Fedorov et al., 2013). In 2003, main sediment discharge occurred during snowmelt in spring and early summer, with highest values of $24 \mathrm{~g} \mathrm{~s}^{-1}$ in June and $0.33 \mathrm{~g} \mathrm{~s}^{-1}$ in August measured in creek 49 (cf. Fig. 1; Fedorov et al., 2013). Much of the sediment is trapped in coastal lagoons at the mouths of several inletstreams, which are dammed by gravelly shore bars generated by ice floe pressure or storms (Glushkova and Smirnov, 2007; Nolan and Brigham-Grette, 2007; Fedorov et al., 2013). The lake is drained by the Enmyvaan River towards the southeast (Fig. 1), which was likely the only discharge during the lake's history (Glushkova and Smirnov, 2007; Nolan and Brigham-Grette, 2007).

The regional climate at Lake El'gygytgyn is cold, dry, and windy (Nolan and Brigham-Grette, 2007), with a mean annual air temperature of $-10.4{ }^{\circ} \mathrm{C}$ and an annual precipitation between 70 and $200 \mathrm{~mm}$ measured between 2002 and 2008 (Nolan, 2013). Strong (up to $21 \mathrm{~m} \mathrm{~s}^{-1}$ ) and very persistent winds (mean of $5.6 \mathrm{~m} \mathrm{~s}^{-1}$ in 2002) of north-northwestern and south-southeastern directions are dominant (Nolan and Brigham-Grette, 2007).

Lake El'gygytgyn is characterized as monomictic and oligotrophic to ultra-oligotrophic, with a low bioproductivity demonstrated by low diatom accumulation (Cremer and Wagner, 2003; Nolan and Brigham-Grette, 2007). Today, the water column is fully mixed with almost complete oxygen saturation during summer, but a thermal stratification occurring during winter (Cremer and Wagner, 2003). During peak glacial periods, in contrast, anoxic bottom water conditions prevailed, resulting from a perennial ice cover (Melles et al., 2007).

According to initial results from ICDP core 5011-1, the Quaternary sediments in the central basin of Lake El'gygytgyn can clearly be differentiated into three pelagic facies (Melles et al., 2012). Dark gray to black, finely laminated silt and clay with sporadic clasts are linked to peak glacial periods (facies A). In contrast, warm and peak warm ("super interglacial") interglacial conditions are reflected by olive gray to brownish, massive to faintly bedded silt (facies B) and laminated brownish silt (facies C), respectively. Beside these pelagic sediments, eight volcanic ash beds (cf. van den Bogaard et al., 2013) as well as numerous mass movement deposits (MMDs) of different type (turbdites, slumps, slides, grain flows, debrites) have been identified (Juschus et al., 2009; Sauerbrey et al., 2013).

\section{Material and methods}

Within the scope of this study, 1019 samples of Lake El'gygytgyn sediments originating from pelagic sediments in core composite of ICDP site 5011-1 (862 samples) and the pilot core Lz1024 (157 samples, locations see Fig. 1) have been analyzed for their grain-size distribution with a sampling resolution of $8 \mathrm{~cm}$. Detailed descriptions about the lithostratigraphy, MMD's, and the creation of the composite profile are given by Melles et al. (2012), Sauerbrey et al. (2013), and by Nowaczyk et al. (2013) and Wennrich et al. (2013b), respectively. The age model of the Lake El'gygytgyn sediment sequence is primarily based on magnetostratigraphic data (Haltia and Nowaczyk, 2013). It is further improved by tuning of sediment proxies (including grain-size data) to the global marine benthic isotope stack of Lisiecki and Raymo (2005, LR04) and to local insolation patterns inferred from orbital parameters according to Laskar et al. (2004), Melles et al. (2012) and Nowaczyk et al. (2013).

Prior to the grain-size analyses, a multi-step chemical treatment procedure was developed to remove autochthonous sediment components without altering the clastic material. The results of each treatment step were subsequently validated by elemental analyses, Fourier-transformed infrared spectroscopy (FTIRS), X-ray diffraction (XRD), scanning electron microscopy (SEM) and optical microscopy. In a first step, approximately $0.75 \mathrm{~g}$ of dry sediment was treated with $15 \mathrm{~mL} \mathrm{H}_{2} \mathrm{O}_{2}\left(30 \% \mathrm{v} / \mathrm{v}, 50^{\circ} \mathrm{C}, 18 \mathrm{~h}\right)$ to remove organic remains. Subsequently, authigenic precipitated vivianite $\left((\mathrm{Fe})_{3}\left(\mathrm{PO}_{4}\right)_{2} \cdot 8 \mathrm{H}_{2} \mathrm{O}\right)$ was dissolved according to Asikainen et al. (2007) by treating the sediment with $15 \mathrm{~mL}$ $\mathrm{HNO}_{3}\left(0.5 \mathrm{M}, 50^{\circ} \mathrm{C}, 5 \mathrm{~h}, 30\right.$ min shaking in between $)$. Finally, biogenic silica (opal), whose content can exceed $50 \%$ in Lake El'gygytgyn sediments (Vogel et al., 2013), was removed by adding $2 \times 15 \mathrm{~mL} \mathrm{NaOH}\left(1 \mathrm{M}, 85^{\circ} \mathrm{C}, 30 \mathrm{~min}\right)$ with manual shaking during the reaction. Between the single pre-treatment steps, the samples were centrifuged and neutralized with deionized (DI) water. The remaining sediment fraction was dispersed in $60 \mathrm{~mL}$ of demineralized and degassed water, mixed with $\mathrm{Na}_{4} \mathrm{P}_{2} \mathrm{O}_{7}(\mathrm{~m} / \mathrm{v}, 0.05 \%)$ and shaken for $12 \mathrm{~h}$. Prior to the analysis, samples were ultrasonified for one minute to remove air bubbles and to achieve redispersing. In a last step the sediment was sieved to $600 \mu \mathrm{m}$, as previous studies have shown that coarse sand- and gravelsized particles only sporadically occur in Lake El'gygytgyn sediments (Asikainen et al., 2007). Single, coarse grains in the sediment produced big errors during grain-size analyses with the particle analyzer.

Grain-size analyses were performed using a Saturn DigiSizer 5200 laser particle analyzer, equipped with a Master Tech 52 autosampler (Micromeritics Co., USA). The analyzer is able to detect particle diameters between 0.1 and $1000 \mu \mathrm{m}$. For the measurement, the flow rate was set to $10 \mathrm{~L} \mathrm{~min}^{-1}$ and the obscuration was adjusted to $20 \%$. The 


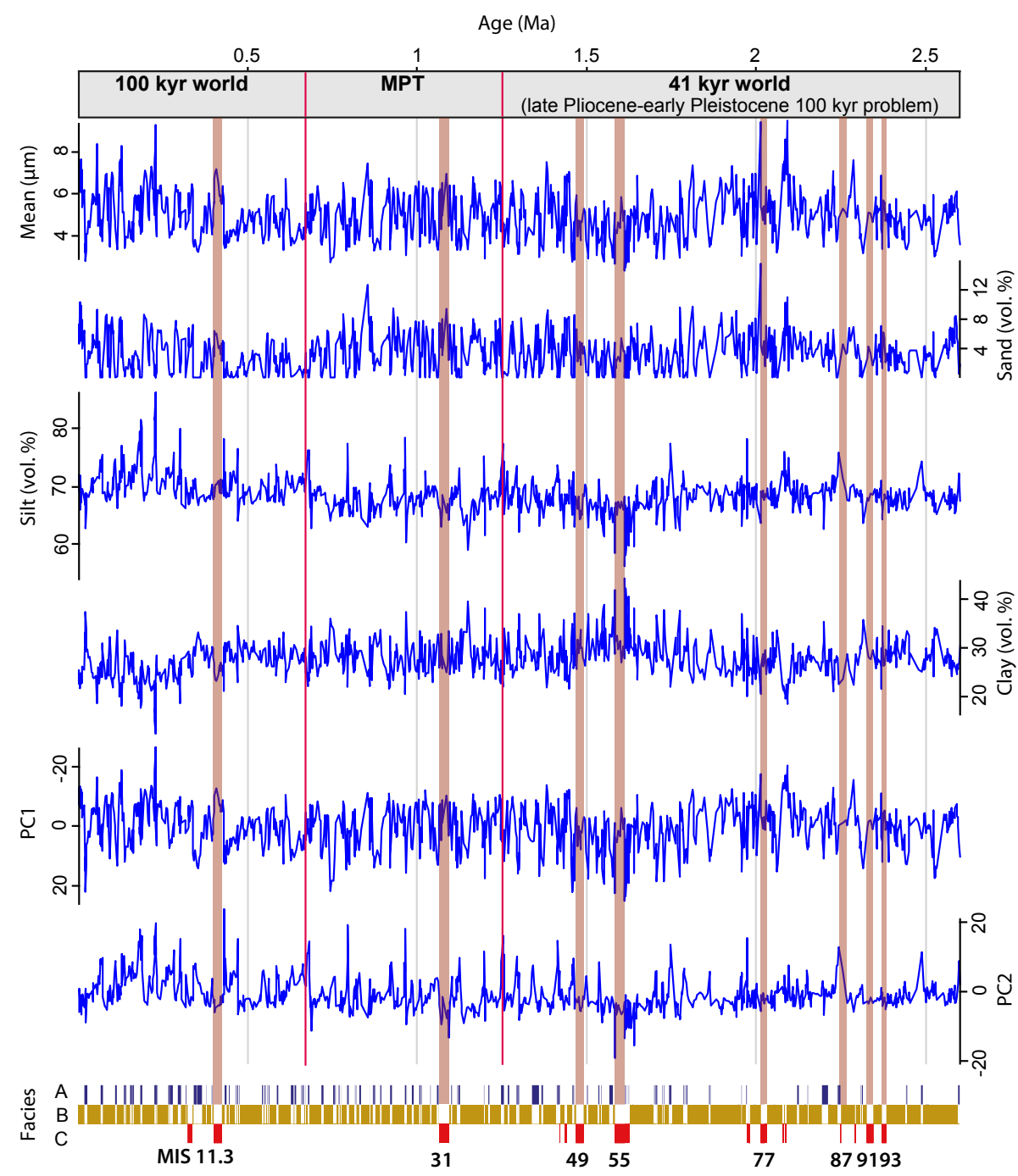

Fig. 2. Selected grain-size parameters (mean, sand, silt, clay) and sample scores of PC1 and PC2 in the Quaternary sediments of the core composite at ICDP site 5011-1 in central Lake El'gygytgyn. The timing of the Middle Pleistocene transition (MPT) from the 41 kyr world, including the Pliocene-early Pleistocene $100 \mathrm{kyr}$ problem after Nie et al. (2008), to the $100 \mathrm{kyr}$ world is derived from the time series analysis (cf. Fig. 6). Facies bar was modified from Melles et al. (2012); marine isotope stages of "super interglacial" facies C (after Melles et al., 2012) are labeled below.

grain-size distribution of three measurements was finally averaged.

Grain-size statistics were calculated with the software GRADISTAT version 8.0 (Blott and Pye, 2001), and are given according to the method by Folk and Ward (1957). Furthermore, a PCA was calculated with the software XLSTAT (Addinsoft Corp.). After an initial linear correlation test of the variables and standardization of the data, the PCA was carried out on the volume frequency of each grain diameter measured by the laser particle analyzer. The grain-size fractions as well as the mean, median and mode values were chosen as additional variables to simplify the visualization of the results.
For time series analysis of the PCA results, the bulk spectrum of the temporally unevenly spaced samples was calculated using the Fortran 90 program REDFIT by Schulz and Mudelsee (2002). Evolutionary spectra of the grain-size data and the benthic marine isotope stack LR04 (Lisiecki and Raymo, 2005) were plotted with the software package ESALAB (Weber et al., 2010).

\section{Results}

\subsection{Grain-size data}

Variations in the grain-size distributions are rather small, but still distinct (Fig. 2). The sand content does not exceed 


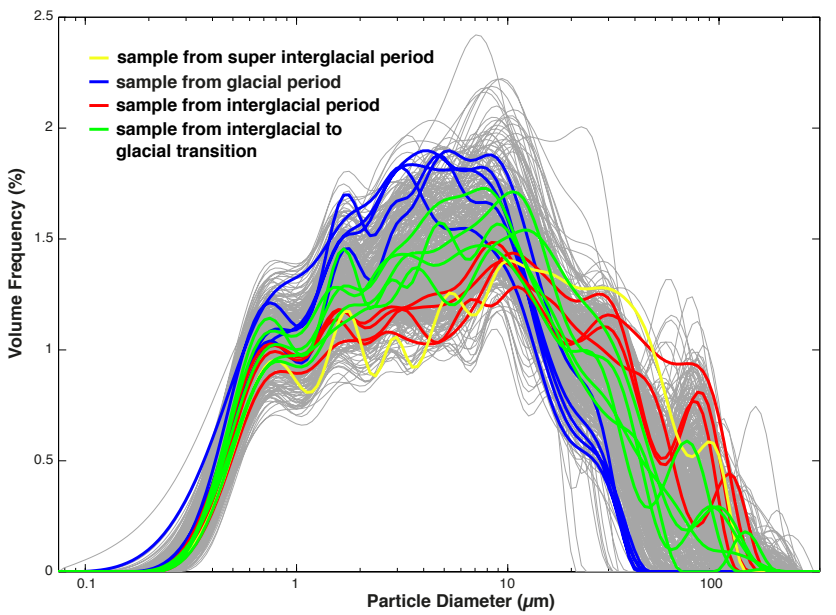

Fig. 3. Grain-size distributions of all analyzed samples from ICDP core 5011-1: blue: samples from glacial periods (facies A); green: samples from interglacial-to-glacial transitions; red: samples from interglacial periods (facies B); yellow: samples from super interglacial conditions (facies $\mathrm{C}$ ).

$15.5 \%$, with medium sand being the coarsest grain-size fraction that occurs. The average silt and clay contents are about 69.2 and $27.7 \%$, respectively, showing minor fluctuations of not more than $15 \%$ within both fractions. The mean values range between 2.5 and $9.3 \mu \mathrm{m}$ (after Folk and Ward, 1957) and, thus, are classified as very fine $(2-4 \mu \mathrm{m})$ to medium silt $(8-16 \mu \mathrm{m})$. In general, this corresponds to earlier investigations on the grain-size distributions of the past $65 \mathrm{kyr}$ in Lake El'gygytgyn (Asikainen et al., 2007).

Characteristic grain-size distribution patterns that describe the pelagic sediments of Lake El'gygytgyn at ICDP site 5011-1 are shown in Fig. 3. Samples from peak glacial periods (facies A) are fine-grained, do not contain any sand and mostly show a trimodal distribution, eventually including a double peak around $10 \mu \mathrm{m}$ (Fig. 3, blue). Their grainsize distributions are commonly slightly asymmetric, which is caused by the lack of a normal tailing to coarse sediments and a coarse-skewed shoulder. Samples from interglacial (facies B) and super interglacial (facies C) periods are comparable (Fig. 3, red and yellow). Both sediment types comprise sand, are coarser than deposits from facies A, and are poorly sorted as indicated by the polymodal pattern of the grainsize distribution. A common feature of grain-size distributions from warm time periods is the lack of normal tailing but the occurrence of a peak or coarse-skewed shoulder at approximately $100 \mu \mathrm{m}$ (Fig. 3). Sediments from climatic transitions (Fig. 3, green) are commonly finer than interglacial period deposits and coarser than glacial period deposits. The grain-size distributions can be comparable to typical patterns of glacial or interglacial sediments, but most transitional deposits appear polymodal and exhibit a peak or coarse-skewed shoulder at around $100 \mu \mathrm{m}$.

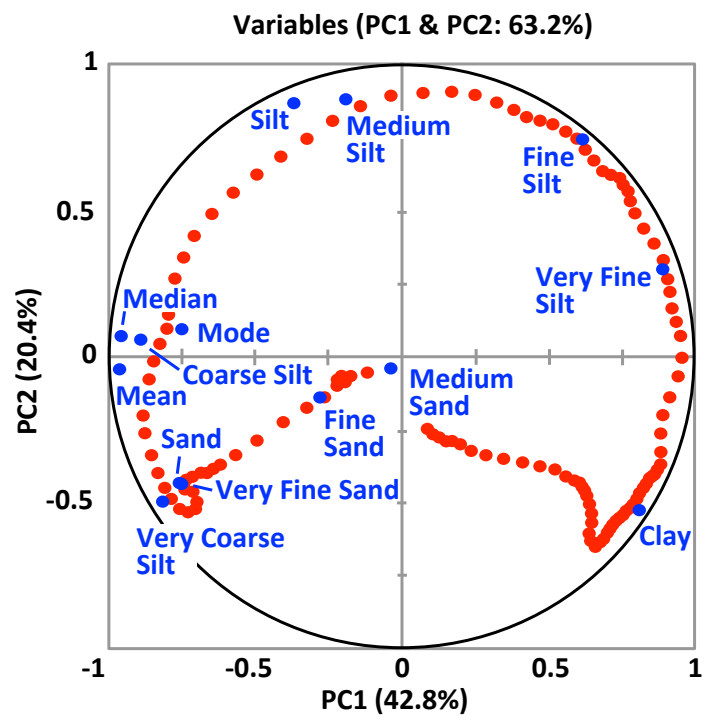

- active variables additional variables

Fig. 4. Results of the PCA of the raw grain-size data (PC1 and PC2). Red dots (active variables) represent specific grain diameters measured by the laser particle analyzer. Selected grain-size fractions and parameters were chosen as additional variables (blue dots) for visualization of the results and are not directly included into the PCA calculations. PC1 (42.8\%) and PC2 (20.4\%) together comprise about $63.2 \%$ of the total variance in the data set. The active variables clearly show a horseshoe pattern (for further explanations see text)

\subsection{PCA}

The PCA of the pelagic sediment yield 3 major principal components (PCs) explaining $75.4 \%$ of the total variance in the grain-size data, with $\mathrm{PC} 1, \mathrm{PC} 2$ and $\mathrm{PC} 3$ covering variances of $42.8,20.4$, and $12.2 \%$, respectively. The plot of the active variables (PC1 vs. PC2; variance: $63.2 \%$; Fig. 4) clearly shows an arch spanning from clay to very coarse silt (Fig. 4), with highest negative factor loadings of PC1 revealing a grain diameter of $23.6 \mu \mathrm{m}$ (coarse silt) and highest positives of $1.9 \mu \mathrm{m}$ (clay to very fine silt). Grain diameters coarser than $44.5 \mu \mathrm{m}$ (very coarse silt to medium sand) and finer than $0.6 \mu \mathrm{m}$ (clay) focus to the origin of the diagram, which results in a horseshoe pattern (Fig. 4). The sample scores of PC1 (Fig. 2) show a high correlation to the mean $\left(R^{2}=0.93\right)$ and the median values $\left(R^{2}=0.91\right)$, whereas only a weaker correspondence to the mode values $\left(R^{2}=0.56\right)$ is noticeable. In contrast, PC2 is highly correlated to medium silt $\left(R^{2}=0.83\right)$ and PC3 is not correlated to any grain-size fraction.

\subsection{Time series analysis}

To gain insight into the frequency of the grain-size data, time series analyses of PC1 samples scores have been performed. The bulk spectrum yields three important peaks with 
dominant oscillations at $98.5,40.6$, and $22.9 \mathrm{kyr}$, which exceed the significance level of $99 \% \chi^{2}$ (Fig. 5).

As evolutionary power spectrum of PC1 sample scores (Fig. 6a) was carried with a window width of $240 \mathrm{ka}$ and overlapping window segments were used for the calculations, the reported time period is between 2478 and $120 \mathrm{ka}$. During this period, the evolutionary power spectrum yields distinct variations in the relative power of the three dominate cycles $(98.5,40.6$, and $22.9 \mathrm{kyr})$. The $98.5 \mathrm{kyr}$ period is highly variable throughout the analyzed time period, with a strong relative power prior to 2300 and from 2100 to $1800 \mathrm{ka}$, from 1250 to $1000 \mathrm{ka}$, and after $800 \mathrm{ka}$, but a weak dominance in the periods 2200 to $2100 \mathrm{ka}, 1800$ to $1600 \mathrm{ka}$ and 1000 to $800 \mathrm{ka}$. The $40.6 \mathrm{kyr}$ cycle is more consistent with a strong relative power from 2400 to $1250 \mathrm{ka}$ and from 950 to $670 \mathrm{ka}$, whereas a low signal occurs around $1750 \mathrm{ka}$ and after $670 \mathrm{ka}$. The $22.9 \mathrm{kyr}$ cycle occurs from 1900 to $1300 \mathrm{ka}$, from 1100 to $900 \mathrm{ka}$, and during two short time periods at 2250 and $130 \mathrm{ka}$.

\section{Discussion}

\subsection{Sedimentation processes at Lake El'gygytgyn}

The Quaternary grain-size variability of core 5011-1 from Lake El'gygytgyn is strongly connected to climate variation, with coarse-grained, polymodal distributed sediments occurring during warm periods and fine-grained, trimodal distributed deposits during cold periods (Fig. 3). Grain-size distributions from samples deposited during a transition from interglacial to glacial periods appear mostly polymodal but are less coarse than samples from warm conditions (Fig. 3). The climate dependency of the grain-size distributions is also confirmed by a comparison of the mean grain size to other climate-dependent proxies of the Lake El'gygytgyn record (cf. Fig. 7). The Si/Ti ratio is a measure of the biogenic silica content (BSi) in the sediment and, thus, of the primary production by diatoms if grain-size effects by XRF scanning can be excluded (Melles et al., 2007, 2012; Vogel et al., 2013; Wennrich et al., 2013b). High Si/Ti ratios reflect a high content of BSi in the sediments, which is related to high primary production in the lake under warm climate conditions (Melles et al., 2007, 2012; Vogel et al., 2013; Wennrich et al., 2013b). For the analyzed data, the grain-size distribution is independent from the content of BSi in the sediment as diatoms were removed during sample pre-treatment for grain-size analyses. As both proxies show very similar variations, this supports the assumption of climate-dependent clastic sedimentation processes at Lake El'gygytgyn (Fig. 7).

As shown for modern conditions, the supply of clastic material to Lake El'gygytgyn is mainly restricted to spring and early summer, when snowmelt and warm temperatures result in the availability of fluvial discharge (cf. Fedorov et al., 2013). Additionally, the thickness of the active layer of

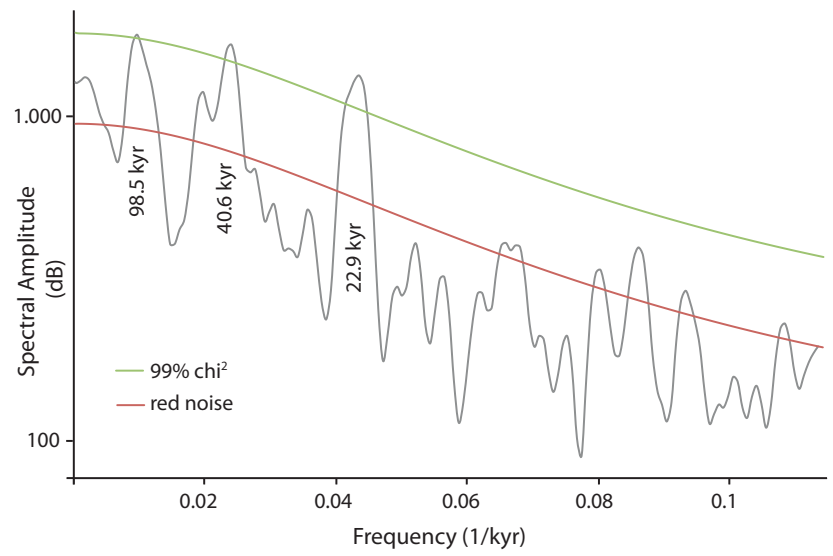

Fig. 5. Bias-corrected spectrum of sample scores of PC1 using the software REDFIT38, applying the Lomb-Scargle periodogram for unevenly spaced time series in combination with the Welch's overlapped segment averaging procedure (Mudelsee et al., 2009). Number of segments $n_{50}=14$; window type: boxcar; red line: red noise level; green line: $99 \%$ false-alarm level $\left(\chi^{2}\right)$. Significant cycles at $98.5,40.6$ and $22.9 \mathrm{kyr}$ exceed both the red noise and the confidence level.

the local permafrost should be linked to the availability of clastic material. During snowmelt, even pebble- to cobblesized rocks as well as clumps of tundra are transported to the beach and close to the shoreline in the lake (cf. Asikainen et al., 2007; Nolan and Brigham-Grette, 2007). Coarse material may be filtered by the shore bars, explaining the lack of a normal tailing to coarse sediments in Lake El'gygytgyn deposits. Subsequently, sand-sized and finer sediments are redistributed by a wind-induced current pattern in the lake. The geochemical, mineralogical and sedimentological analyses of surface sediments from Lake El'gygytgyn, inlet streams, and source rocks have shown that clastic material that is transported to the lake is re-distributed by lake-internal currents (Wennrich et al., 2013a). These current systems are induced by strong wind conditions of predominantly northern or southern directions and result in the occurrence of a suspension cloud focused to the lake center (Wennrich et al., 2013a). In relation to the suspension cloud, a tongue of coarse-grained and poorly sorted sediments focused to the lake center can be observed in the surface sediments of Lake El'gygytgyn (cf. Wennrich et al., 2013a). Wind speed, current speed of the water body and transport energy for transportation of clastic material are very closely connected within this sedimentation system. Surface sediments from central parts of Lake El'gygytgyn exhibit comparable grain-size diameters and distribution patterns to sediments from interglacial periods. This implies that sedimentation processes described for the modern conditions persisted during interglacial periods throughout the entire Quaternary. In addition, no remarkable differences in the grain-size distributions from interglacial facies B and super interglacial 


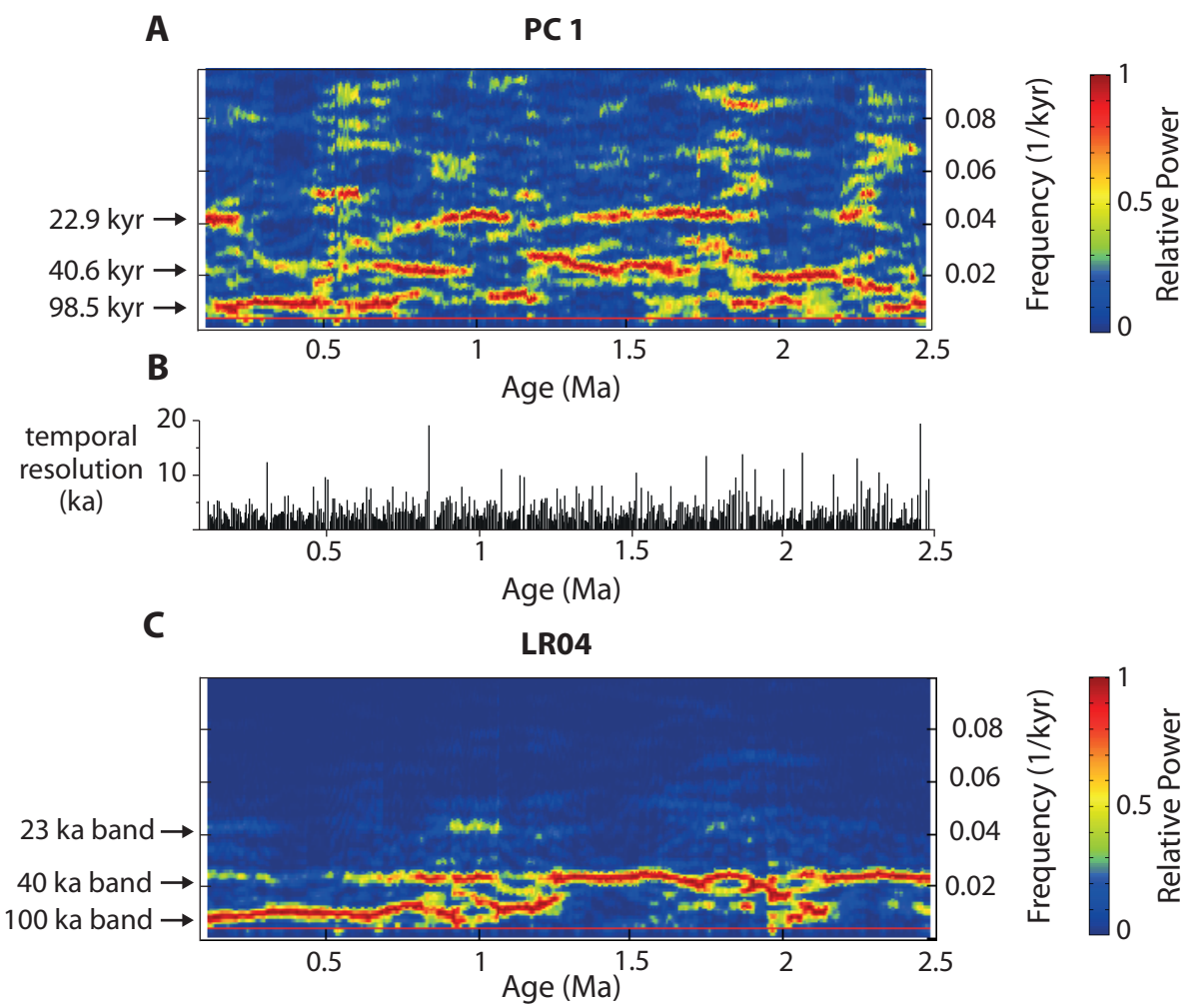

Fig. 6. (A) Evolutionary power spectrum of sample scores of PC1 from 120 to $2478 \mathrm{ka}$, resulting from the chosen window width of $240 \mathrm{ka}$ (window type: boxcar). The used software ESALAB (Weber et al., 2010) is based on the same algorithms as REDFIT38. (B) Plot of the temporal resolution of the grain-size data versus time. The length of each bar represents the time period to the next sample below. (C) Evolutionary power spectrum of LR04 (Lisiecki and Raymo, 2005) applying the same settings as in (A).

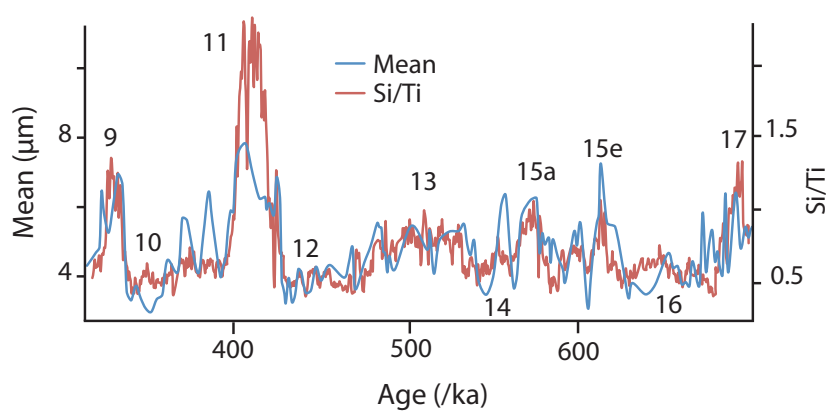

Fig. 7. Comparison of the mean values (after Folk and Ward, 1957) and the $\mathrm{Si} / \mathrm{Ti}$ ratio as a proxy for bioproductivity in Lake El'gygytgyn between marine isotope stages 17 and 9. This short time period was exemplarily chosen to visualize grain-size and $\mathrm{Si} / \mathrm{Ti}$ variability during several glacial-interglacial cycles including the super interglacial MIS11. The relationship is consistent over the entire record. Variations on a glacial-interglacial timescale but also of higher frequency are well reflected by the grain-size data. Grain-size distributions during MIS11 do not differ compared to other interglacials. facies $C$ could be observed (cf. Figs. 2, 3 and 7). Thus, the maximum transport energy during both interglacial periods was likely comparable. Variable transport energies during both types of interglacials could be indicated by the typical polymodal pattern of the grain-size distributions and the occurrence of the coarse-skewed shoulder or independent peak at $\sim 100 \mu \mathrm{m}$ (cf. Fig. 3a). However, polymodal grain-size distributions could also be triggered by additional sedimentation processes, such as eolian or ice floe transportation. For modern conditions, eolian sediment input to Lake El'gygytgyn was estimated by measuring the particle concentration of the snow on the lake ice prior to the ice breakup. The amount of the eolian supply is calculated as 2 to $5 \%$ of the total sediment deposition (Fedorov et al., 2013). After ice breakup, random ice floe transport of sediments of fluvial origin could have significantly contributed to the sediment supply of ICDP site 5011-1. Modern observations recorded sediment supply by inlet streams onto the ice cover during snowmelt, wherefrom the sediment is periodically flushed out when the temperatures are high enough (Fedorov et al., 2013). Sediment supply onto the ice cover and subsequent redistribution by ice floe transportation is also described for other seasonally ice-covered lakes, e.g. for Lake Baikal (Vologina et al., 2005). 
Varying transport energies in the lake-water body, eolian supply and ice floe transportation can explain the coarsegrained, poorly sorted occurrence of interglacial grain-size distributions. The finer, better-sorted sediments from glacial periods, in contrast, suggest low transport energies and probably reduced eolian supply or ice floe transportation. Reduced eolian supply and ice floe transportation can be explained by a very short ice-free summer season or a perennial ice cover. An enhanced deposition of eolian deposits at the end of a long period with a perennial ice cover is not observed in the data, likely because of the low sample resolution. However, eolian sediment can be deposited despite a perennial ice cover during cold and dry periods (Asikainen et al., 2007; Melles et al., 2007). Material of eolian origin is able to move through the ice along grain boundaries and vertical conduits, whereby it might be compacted to 1-2 mm clasts (Nolan, 2013). These clasts are not observed in the grain-size data, likely because they are destroyed during the sample pretreatment. A perennial lake ice cover also excludes the redistribution of clastic material by a wind-induced current pattern. In general, sediment supply to Lake El'gygytgyn under such conditions is widely restricted to seasonal moats around the perennial lake ice, formed in late summer (Asikainen et al., 2007; Melles et al., 2007). The transportation of clastic material to the lake center likely depends on relatively weak lake-internal currents triggered by temperature differences between the seasonal moats with warmer water temperatures and deeper parts of Lake El'gygytgyn. The formation of a perennial lake-ice cover and the occurrence of seasonal moats predominantly depends on the summer temperature (Nolan, 2013). Summer temperature also triggers the thickness of the active layer of the permafrost and restricts the availability of water as a major transport medium for clastic material. A thin active layer and limited water availability hamper the supply of coarse material to the lake. Overall, the deposition of clastic material at ICDP site 5011-1 seems to be very sensitive to variations of the local summer temperature at Lake El'gygytgyn. Gradual transitions from warm to cold conditions on an interglacial-glacial timescale are well reflected by the mean grain size, and even higher amplitude variations (e.g. between MIS 11 and 10, Fig. 7) are present in the data. This implies gradual rather than abrupt changes of the sedimentation processes at Lake El'gygytgyn during such transitions.

\subsection{PCA}

Factor loadings of PC1 yield the most important grain diameter (fractions) contributing to the grain-size distribution (Fig. 4). High positive or negative factor loadings imply a high importance of the coarse silt or the very fine silt fraction, respectively. As variations in the grain-size data are primarily attributed to climate variability, sample scores of PC1 can be interpreted to represent climate variations. High negative PC1 scores are associated with warmer climate conditions with ice-free conditions during summer and enhanced sedimentation of coarse silt. In contrast, high positive PC1 scores are linked to glacial climate conditions and the enrichment of very fine silt. Silt, in particular medium silt, shows the weakest correlation to PC1 but high factor loading on PC2. The high correlation of medium silt to PC2 is apparently mainly triggered by the occurrence of the horseshoe pattern (Fig. 4). The horseshoe pattern is a mathematic artifact in PCA results (cf. Kendall, 1971; Gauch et al., 1977), which occurs if the analyzed data set is only influenced by one long gradient and each variable (inhere: grain diameter) is successively replaced by the next one, resulting in a unimodal response to the gradient (Swan, 1970; Gauch et al., 1977). Thus, PCA results substantiate the interpretation that grain-size variations of Lake El'gygytgyn sediments predominantly reflect variations in the sedimentary processes controlled by climate influences. Additional processes, such as lake-level variations or changes in the geomorphic shape of the catchment, have only limited influence on the grain-size distribution. In line with this result, a direct connection between the grain-size data and lake-level fluctuations recorded by the occurrence of lacustrine terraces in the area and in sediment cores from marginal parts of the lake (cf. Juschus et al., 2011) is not present.

\subsection{Time series analysis}

To distinguish between time periods, which are dominated by global glacial-interglacial or shorter-term variations, a time series analysis on PC1 sample scores was carried out. As the age model of core 5011-1 was derived by tuning sediment proxies with local insolation and the global marine isotope stack LR04 (Melles et al., 2012; Nowaczyk et al., 2013), the bulk spectrum (Fig. 5) yields dominant oscillations above the $99 \% \chi^{2}$ confidence level at Milankovitch's eccentricity (98.5 kyr), obliquity (40.6 kyr) and precession oscillations (22.9 kyr). Despite the tuned age model of core 5011-1, the relative dominance of these three oscillations clearly differs from these of LR04 during the Quaternary (Fig. 6). Oscillations of higher frequency that exceed the red noise level (cf. Fig. 5) were not included in further analyses, as the temporal resolution of the grain-size data ranges between 0.02 and 19.79 ka (average: 2.56 ka, cf. Fig. 6b). Cycles of 98.5 and $40.6 \mathrm{ka}$ are interpreted to be a result of global climate variability and variations of the global ice volume, as reflected by marine isotope stack LR04 (Lisiecki and Raymo, 2005; cf. Fig. 6c). In contrast, the $22.9 \mathrm{ka}$ band is closely connected to local orbital precession forcing at the latitude of Lake El'gygytgyn, with coarser grain-size distributions associated with high insolation values. Consequently, icefree summertime is extended during high insolation forcing, which is consistent with results of previous studies on the sedimentation pattern of Lake El'gygytgyns, e.g. magnetic susceptibility and TOC data (Melles et al., 2007; Nowaczyk et al., 2007). On the other hand, the strong precession cycle 
in the Lake El'gygytgyn grain-size data could be a latitudinal teleconnection, as the precession cycle is rather weak in polar but stronger in equatorial regions (Berger and Loutre, 1991). Tropical to subtropical climate oscillations that are associated with variations on a precession cycle are the East Asian Monsoon (Sun et al., 2006) and the El Niño-Southern Oscillation (Tudhope et al., 2001). In transect from Lake El'gygytgyn to southern direction, winter monsoon variability on a precession cycle is recorded from the Chinese Loess Plateau (Sun et al., 2006).

During the early Pleistocene (2600 to $780 \mathrm{ka}$; see also Fig. 2), when global climate conditions were dominated by the $41 \mathrm{kyr}$ band (e.g. Clark et al., 2006), similarities and dissimilarities between 5011-1 and LR04 occur (Fig. 6). The strong oscillation of the $41.7 \mathrm{kyr}$ cycle in the grainsize data of 5011-1 well reflect global climate variability on the obliquity oscillation band. In contrast, the $98.5 \mathrm{kyr}$ cycle in the grain-size data is more variable, with a strong response to climate forcing between 2450 and $2300 \mathrm{ka}$ and between 2100 and $1800 \mathrm{ka}$, and a reduced power between 1800 and $1600 \mathrm{ka}$ (Fig. 6). These findings partly agree with descriptions of Nie et al. (2008) about the $100 \mathrm{ka}$ band during the early Pleistocene. Following their description of the "late Pliocene-early Pleistocene $100 \mathrm{kyr}$ problem", there is a strong response of climate proxies between 3000 and $1800 \mathrm{ka}$, although forcing is strong between 2300 and $1300 \mathrm{ka}$. However, Lake El'gygytgyn grain-size data indicate only a weak $98.5 \mathrm{kyr}$ cycle between 2300 and $2100 \mathrm{ka}$.

During the early Pleistocene, the $22.9 \mathrm{kyr}$ precession band is strong around $2250 \mathrm{ka}$ and between 1900 and $1300 \mathrm{ka}$ when relative eccentricity or obliquity powers are low. Thus, the precession band at Lake El'gygytgyn mostly interplays with the eccentricity band and is therefore closely connected with the late Pliocene-early Pleistocene $100 \mathrm{kyr}$ problem. The absence of the $23 \mathrm{ka}$ band between 3000 and $1000 \mathrm{ka}$ in global benthic isotope records (cf. Fig. 6) despite a strong precession cycle at all latitudes has been explained with an out-of-phase ice sheet growth and melt at each pole (Raymo et al., 2006). Grain-size data at Lake El'gygytgyn is not directly coupled to global ice-volume variability and, thus, shows the $23 \mathrm{ka}$ precession band to be important for the climate conditions during specific time intervals. Variations on a $23 \mathrm{ka}$ oscillation band during the early Pleistocene are also reported from the Chinese Loess Plateau (Sun et al., 2006) and African dust records (deMenocal, 1995).

The time periods of the Middle Pleistocene transition (MPT; see also Fig. 2) and the late Pleistocene are marked by the transition of the climate variability from the dominance of the obliquity oscillation to eccentricity oscillation (e.g. Clark et al., 2006). In our data set this transition is rather gradual with an initial onset of the $98.5 \mathrm{kyr}$ cycle at $1250 \mathrm{ka}$, low power from 1000 to $800 \mathrm{ka}$ and strong power afterwards until at least $130 \mathrm{ka}$. A weakening of the $100 \mathrm{ka}$ eccentricity band around $1000 \mathrm{ka}$ is also present in LR04 (Fig. 6c). At
Lake El'gygytgyn, this period until $800 \mathrm{ka}$ is characterized by an initially strong $22.9 \mathrm{kyr}$ cycle and subsequent strong $40.6 \mathrm{kyr}$ cycle. The decreasing relative power of the obliquity oscillation during the late Pleistocene implies that the MPT at Lake El'gygytgyn lasted from 1250 to $670 \mathrm{ka}$. Such a gradual transition is also described for LR04 with an initial onset at $1250 \mathrm{ka}$, a disturbance of the eccentricity cycle for $100 \mathrm{kyr}$ around $1000 \mathrm{ka}$, and a completion of the transition to the $100 \mathrm{kyr}$ world at $700 \mathrm{ka}$ (Clark et al., 2006). The mechanism leading to the emergence of the $100 \mathrm{kyr}$ band is hypothesized to have been triggered by a long-term cooling trend induced by decreasing $p \mathrm{CO}_{2}$ (Berger et al., 1999; Tziperman and Gildor, 2003) and/or increasing ice sheet thickness due to exposure of high-friction crystalline bedrock (Clark and Pollard, 1998), whereas orbital forcing can be excluded (Clark et al., 2006).

\section{Conclusions}

Variations in the grain-size distribution of Lake El'gygytgyn sediments during the past 2600 ka have shown to be mainly influenced by summer temperature and thus, by global and regional climate conditions. Main factors triggering the clastic sedimentation in the lake are assumed to be the existence and duration of an annual lake-ice cover, the permafrost stability around the lake and the intensity of fluvial transport processes in the catchment. Studies on the modern sedimentation in the lake have shown that a wind-induced current pattern of different strengths triggers the occurrence of coarse-grained deposits at the center of the lake during icefree periods (Wennrich et al., 2013a). Our data suggest that this process persisted throughout the entire Quaternary. Under glacial climate conditions, sediment supply to the lake is likely restricted to seasonal moats close to the shore and to vertical conduits in the ice.

Principal Component Analysis allowed identifying most important grain-size fractions attributed to variations in the data set. Coarse silt and very fine silt could be emphasized to be the major players in climate-dependent variations in the grain-size data, whereas medium silt does not show this climate dependency.

Time series analysis reveals major oscillation and their relative dominance in the grain-size data during the Quaternary. It can be concluded that duration of annual lake-ice cover and thickness of the active layer during summer are triggered by global glacial-interglacial cycles $(98.5,40.6 \mathrm{kyr})$ and by local insolation forcing and/or latitudinal teleconnections (precession band, $22.9 \mathrm{kyr}$ ). Early Pleistocene variations on a $98.5 \mathrm{kyr}$ oscillation band partly agree with descriptions of the late Pliocene-early Pleistocene $100 \mathrm{kyr}$ problem" by Nie et al. (2008). Additionally, our data suggest an interplay of the 98.5 and $22.9 \mathrm{kyr}$ cycles during the early Pleistocene. Oscillations on the eccentricity band ( $98.5 \mathrm{kyr}$ ) likely reflect global climate variability at Lake El'gygytgyn, whereas 
variations on the precession band $(22.9 \mathrm{kyr})$ are probably connected with regional insolation variations or latitudinal climatic teleconnections. The MPT is well reflected by our data between 1250 and $670 \mathrm{ka}$.

Acknowledgements. Funding for the drilling at Lake El'gygytgyn was provided by the International Continental Scientific Drilling Program (ICDP), the US National Science Foundation (NSF), the German Federal Ministry of Education and Research (BMBF), Alfred Wegener Institute (AWI) and GeoForschungsZentrum Potsdam (GFZ), the Russian Academy of Sciences Far East Branch (RAS FEB), the Russian Foundation for Basic Research (RFBR), and the Austrian Federal Ministry of Science and Research (BMWF). The Russian GLAD 800 drilling system was developed and operated by DOSECC Inc., and LacCore, at the University of Minnesota, handled core curation. This study was financially supported by the BMBF (grant no. 03G0642A) and the German Research Foundation (DFG, grant nos. WA 2109/11 and ME 1169/21). The laboratory work was carried by out with the assistance of various students under the guidance of Nicole Mantke. Nicole Mantke also contributed together with Hendrik Vogel to the development of the pre-treatment steps prior to the grain-size analyses. Furthermore, we thank Nikolaos Tougiannidis and Michael Weber for providing the software ESALAB and assistance with the time series analyses. Conrad Kopsch is acknowledged for providing topographic data, which was used by Andreas Dehnert for the creation of Fig. 1b within the scope of a diploma thesis.

Edited by: T. Cook

\section{References}

ACIA: Impacts of a Warming Arctic-Arctic Climate Impact Assessment Cambridge and New York, Cambridge University Press, 144 pp., 2004.

An, Z. S., Kukla, G., Porter, S. C., and Xiao, J. L.: Late quaternary dust flow on the Chinese loess plateau, Catena, 18, 125-132, 1991.

Asikainen, C. A., Francus, P., and Brigham-Grette, J.: Sedimentology, clay mineralogy and grain-size as indicators of $65 \mathrm{ka}$ of climate change from El'gygytgyn Crater Lake, Northeastern Siberia, J. Paleolimnol., 37, 105-122, doi:10.1007/s10933-0069026-5, 2007.

Axford, Y., Briner, J. P., Cooke, C. A., Francis, D. R., Michelutti, N., Miller, G. H., Smol, J. P., Thomas, E. K., Wilson, C. R., and Wolfe, A. P.: Recent changes in a remote Arctic lake are unique within the past 200,000 years, P. Natl. Acad. Sci., 106, 1844318446, doi:10.1073/pnas.0907094106, 2009.

Berger, A. and Loutre, M. F.: Insolation values for the climate of the last 10 million years, Quaternary Sci. Rev., 10, 297-317, doi:10.1016/0277-3791(91)90033-Q, 1991.

Berger, A., Li, X., and Loutre, M.: Modeling northern hemisphere ice volume over the last $3 \mathrm{Ma}$, Quaternary Sci. Rev., 18, 1-11, 1999.

Blott, S. J. and Pye, K.: GRADISTAT: A grain size distribution and statistics package for the analysis of unconsolidated sediments, Earth Surf. Proc. Land., 26, 1237-1248, 2001.
Brigham-Grette, J., Melles, M., and Minyuk, P.: Overview and significance of a $250 \mathrm{ka}$ paleoclimate record from El'gygytgyn Crater Lake, NE Russia, J. Paleolimnol., 37, 1-16, 2007.

Clark, C. D. and Pollard, D.: Origin of the Middle Pleistocene transition by ice sheet erosion of regolith, Paleoceanography, 13, 19, 1998.

Clark, P. U., Archer, D., Pollard, D., Blum, J. D., Rial, J. A., Brovkin, V., Mix, A. C., Pisias, N. G., and Roy, M.: The middle Pleistocene transition: characteristics, mechanisms, and implications for long-term changes in atmospheric $p \mathrm{CO}_{2}$, Quaternary Sci. Rev., 25, 3150-3184, doi:10.1016/j.quascirev.2006.07.008, 2006.

Cremer, H. and Wagner, B.: The diatom flora in the ultraoligotrophic Lake EI'gygytgyn, Chukotka, Polar Biol., 26, 105114, doi:10.1007/s00300-002-0445-0, 2003.

deMenocal, P. B.: Plio-Pleistocene African Climate, Science, 270, 53-59, 1995.

Dietz, R. S. and McHone, J. F.: El'gygytgyn: Probably the world largest meteorite crater, Geology, 4, 391-392, 1977.

Fedorov, G. and Kupolov, A.: Gas Mercury Survey in the El'gygytgyn Crater, in: The Expedition El'gygytgyn Lake 2003 (Siberian Arctic), edited by: Melles, M., Minyuk, P., BrighamGrette, J., and Juschus, O., Reports on polar and marine research, AWI, Bremerhaven, 69-70, 2005.

Fedorov, G., Nolan, M., Brigham-Grette, J., Bolshiyanov, D., Schwamborn, G., and Juschus, O.: Preliminary estimation of Lake El'gygytgyn water balance and sediment income, Clim. Past, 9, 1455-1465, doi:10.5194/cp-9-1455-2013, 2013.

Folk, R. L. and Ward, W. C.: Brazos River bar [Texas]; a study in the significance of grain size parameters, J. Sediment. Res., 27, 3-26, 1957.

Gauch, H. G., Whittaker, R. H., and Wentworth, T. R.: A comparative study of reciprocal averaging and other ordination techniques, J. Ecol., 65, 157-174, 1977.

Glushkova, O. Y. and Smirnov, V. N.: Pliocene to Holocene geomorphic evolution and paleogeography of the El'gygytgyn Lake region, NE Russia, J. Paleolimnol., 37, 37-47, doi:10.1007/s10933-006-9021-x, 2007.

Gurov, E. P. and Gurova, E. P.: Stages of shock metamorphism of volcanic rocks of siliceous composition - Examples from the El'gygytgyn crater (Chukotka), Doklady Academii Nauk UkrSSR, 249, 1197-1201, 1979.

Gurov, E. P., Gurova, E. P., and Rakitskaia, R. B.: Stishovite and coesite in shock-metamorphosed rocks of the El'gygytgyn crater in Chukotka, Akademiia Nauk SSSR Doklady, 248, 213-216, 1979.

Gurov, E. P., Koeberl, C., and Yamnichenko, A.: El'gygytgyn impact crater, Russia: Structure, tectonics, and morphology, Meteor. Planet. Sci., 42, 307-319, 2007.

Haltia, E. M. and Nowaczyk, N. R.: Magnetostratigraphy of sediments from Lake El'gygytgyn ICDP Site 5011-1: paleomagnetic age constraints for the longest paleoclimate record from the continental Arctic, Clim. Past Discuss., 9, 5077-5122, doi:10.5194/cpd-9-5077-2013, 2013.

Johannessen, O. M., Bengtsson, L., Miles, M. W., Kuzmina, S. I., Semenov, V. A., Alekseev, G. V., Nagurnyi, A. P., Zakharov, V. F., Bobylev, L. P., Pettersson, L. H., Hasselmann, K., and Cattle, P.: Artic climate change: observed and modelled temperature and sea-ice variability, Tellus A, 56, 328-341, 2004. 
Juschus, O., Melles, M., Wennrich, V., Nowaczyk, N., BrighamGrette, J., and Minyuk, P.: Sedimentation in Lake Elgygytgyn, NE Russia, during the past 340.000 years, AGU Fall Meeting Abstracts, 11, 1303, 2009.

Juschus, O., Pavlov, M., Schwamborn, G., Preusser, F., Fedorov, G., and Melles, M.: Late Quaternary lake-level changes of Lake El'gygytgyn, NE Siberia, Quaternary Res., 76, 441-451, doi:10.1016/j.yqres.2011.06.010, 2011.

Kashiwaya, K., Yamamoto, A., and Fukuyama, K.: Time variations of erosional force and grain size in Pleistocene lake sediments, Quaternary Res., 28, 61-68, doi:10.1016/0033-5894(87)900330, 1987.

Kashiwaya, K., Ryugo, M., Sakai, T., and Kawai, T.: Long-term climate-limnological oscillation during the past 2.5 million years in Lake Baikal sediments, Geophys. Res. Lett., 25, 659-662, 1998.

Kashiwaya, K., Ochiai, S., and Sakai, T.: Orbit-related long-term climate cycles revealed in a 12-Myr continental record from Lake Baikal, Nature, 410, 71-74, 2001.

Kendall, D. G.: Seriation from abundance matrices, in: Mathematics in the archeological and history siences, edited by: Hodson, F. R., Kendall, D. G., and Tautu, P., Edinburgh University Press, 215252,1971

Laskar, J., Robutel, P., Joutel, F., Gastineau, M., Correia, A. C. M., and Levrard, B.: A long-term numerical solution for the insolation quantities of the Earth, Astron. Astrophys., 428, 261-285, doi:10.1051/0004-6361:20041335, 2004

Layer, P. W.: Argon-40/argon-39 age of the El'gygytgyn impact event, Chukotka, Russia, Meteor. Planet. Sci., 35, 591-599, 2000.

Lisiecki, L. E. and Raymo, M. E.: A Pliocene-Pleistocene stack of 57 globally distributed benthic $\delta^{18} \mathrm{O}$ records, Paleoceanography, 20, PA1003, doi:10.1029/2004pa001071, 2005.

Melles, M., Brigham-Grette, J., Glushkova, O. Y., Minyuk, P. S., Nowaczyk, N. R., and Hubberten, H. W.: Sedimentary geochemistry of core PG1351 from Lake El'gygytgyn - a sensitive record of climate variability in the East Siberian Arctic during the past three glacial-interglacial cycles, J. Paleolimnol., 37, 89-104, doi:10.1007/s10933-006-9025-6, 2007.

Melles, M., Brigham-Grette, J., Minyuk, P., Koeberl, C., Andreev, A., Cook, T., Fedorov, G., Gebhardt, C., Haltia-Hovi, E., Kukkonen, M., Nowaczyk, N., Schwamborn, G., Wennrich, V., and and the El'gygytgyn Scientific Party: The Lake El'gygytgyn Scientific Drilling Project - Conquering Arctic Challenges through Continental Drilling, Scientific Drill., 11, 29-40, 2011.

Melles, M., Brigham-Grette, J., Minyuk, P., Nowaczyk, N., Wennrich, V., Deconto, R., Andersen, P., Andreev, A. A., Coletti, A., Cook, T., Haltia-Hovi, E., Kukkonen, M., Lozhkin, A., Rosén, P., Tarasov, P., Vogel, H., and Wagner, B.: 2.8 Million Years of Artic Climate Change from Lake El'gygytgyn, NE Russia, Science, 337, 315-320, doi:10.1126/science.1222135, 2012.

Moran, K., Backman, J., Brinkhuis, H., Clemens, S. C., Cronin, T., Dickens, G. R., Eynaud, F. D. R., Gattacceca, J. R. M., Jakobsson, M., Jordan, R. W., Kaminski, M., King, J., Koc, N., Krylov, A., Martinez, N., Matthiessen, J., McInroy, D., Moore, T. C., Onodera, J., O’Regan, M., Pälike, H., Rea, B., Rio, D., Sakamoto, T., Smith, D. C., Stein, R., St John, K., Suto, I., Suzuki, N., Takahashi, K., Watanabe, M., Yamamoto, M., Farrell, J., Frank, M., Kubik, P., Jokat, W., and Kristoffersen, Y.: The Cenozoic palaeoenvironment of the Arctic Ocean, Nature, 441, 601-605, 2006.

Mottaghy, D., Schwamborn, G., and Rath, V.: Past climate changes and permafrost depth at the Lake El'gygytgyn site: implications from data and thermal modeling, Clim. Past, 9, 119-133, doi:10.5194/cp-9-119-2013, 2013.

Mudelsee, M., Scholz, D., Röthlisberger, R., Fleitmann, D., Mangini, A., and Wolff, E. W.: Climate spectrum estimation in the presence of timescale errors, Nonlin. Processes Geophys., 16, 43-56, doi:10.5194/npg-16-43-2009, 2009.

Nie, J., King, J., and Fang, X.: Late Pliocene-early Pleistocene 100-ka problem, Geophys. Res. Lett., 35, L21606, doi:10.1029/2008GL035265, 2008.

Niessen, F., Gebhardt, A. C., Kopsch, C., and Wagner, B.: Seismic investigation of the El'gygytgyn impact crater lake (Central Chukotka, NE Siberia): preliminary results, J. Paleolimnol., 37, 49-63, doi:10.1007/s10933-006-9022-9, 2007.

Nolan, M.: Quantitative and qualitative constraints on hind-casting the formation of multiyear lake-ice covers at Lake El'gygytgyn, Clim. Past, 9, 1253-1269, doi:10.5194/cp-9-1253-2013, 2013.

Nolan, M. and Brigham-Grette, J.: Basic hydrology, limnology, and meteorology of modern Lake El'gygytgyn, Siberia, J. Paleolimnol., 37, 17-35, doi:10.1007/s10933-006-9020-y, 2007.

Nolan, M., Cassano, E. N., and Cassano, J. J.: Synoptic climatology and recent climate trends at Lake El'gygytgyn, Clim. Past, 9, 1271-1286, doi:10.5194/cp-9-1271-2013, 2013.

Nowaczyk, N., Melles, M., and Minyuk, P.: A revised age model for core PG1351 from Lake El'gygytgyn, Chukotka, based on magnetic susceptibility variations tuned to northern hemisphere insolation variations, J. Paleolimnol., 37, 65-76, doi:10.1007/s10933-006-9023-8, 2007.

Nowaczyk, N. R., Haltia, E. M., Ulbricht, D., Wennrich, V., Sauerbrey, M. A., Rosén, P., Vogel, H., Francke, A., MeyerJacob, C., Andreev, A. A., and Lozhkin, A. V.: Chronology of Lake El'gygytgyn sediments - a combined magnetostratigraphic, palaeoclimatic and orbital tuning study based on multiparameter analyses, Clim. Past, 9, 2413-2432, doi:10.5194/cp-92413-2013, 2013.

Pienitz, R., Melles, M., and Zolitschka, B.: Results of recent sediment drilling activities in deep crater lakes, Pages News, 3, 117$118,2009$.

Raymo, M. E., Lisiecki, L. E., and Nisancioglu, K. H.: PlioPleistocene ice volume, Antarctic climate, and the global $\delta^{18} \mathrm{O}$ record, Science, 313, 492-495, doi:10.1126/science.1123296, 2006.

Sauerbrey, M. A., Juschus, O., Gebhardt, A. C., Wennrich, V., Nowaczyk, N. R., and Melles, M.: Mass movement deposits in the 3.6 Ma sediment record of Lake El'gygytgyn, Far East Russian Arctic, Clim. Past, 9, 1949-1967, doi:10.5194/cp-9-19492013, 2013.

Schulz, M. and Mudelsee, M.: REDFIT: estimating red-noise spectra directly from unevenly spaced paleoclimatic time series, Comput. Geosci., 28, 421-426, 2002.

Serreze, M. and Francis, J.: The Artic Amplification Debate, Climatic Change, 76, 241-264, 2006. 
Stone, D. B., Layer, P. W., and Raikevich, M. I.: Age and paleomagnetism of the Okhotsk-Chukotka Volcanic Belt (OCVB) near Lake El'gygytgyn, Chukotka, Russia, Stephan Mueller Special Publication Server, 4, 243-260, doi:10.5194/smsps-4-243-2009, 2009.

Sun, J. and Huang, X.: Half-precessional cycles recorded in Chinese loess: response to low-latitude insolation forcing during the Last Interglaciation, Quaternary Sci. Rev., 25, 1065-1072, doi:10.1016/j.quascirev.2005.08.004, 2006.

Sun, Y., Clemens, S. C., An, Z., and Yu, Z.: Astronomical timescale and palaeoclimatic implication of stacked 3.6-Myr monsoon records from the Chinese Loess Plateau, Quaternary Sci. Rev., 25, 33-48, doi:10.1016/j.quascirev.2005.07.005, 2006.

Swan, J. M. A.: An Examination of some ordination problems by use of simulated vegetation data, Ecology, 51, 89-102, 1970.

Thiede, J., Winkler, A., Wolf-Welling, T., Eldholm, O., Myhre, A., Baumann, K.-H., Henrich, R., and Stein, R.: Late Cenozoic history of the Polar North Atlantic: results from ocean drilling, Quaternary Sci. Rev., 17, 185-208, 1998.

Tudhope, A. W., Chilcott, C. P., McCulloch, M. T., Cook, E. R., Chappell, J., Ellam, R. M., Lea, D. W., Lough, J. M., and Shimmield, G. B.: Variability in the El Nino-Southern Oscillation Through a Glacial-Interglacial Cycle, Science, 291, 1511-1517, doi:10.1126/science.1057969, 2001.

Tziperman, E. and Gildor, H.: On the mid-Pleistocene transition to $100 \mathrm{kyr}$ glacial cycles and the asymmetry between glaciation and deglaciation times, Paleoceanography, 18, 1001, doi:10.1029/2001PA000627, 2003.

van den Bogaard, C., Jensen, B. J. L., Pearce, N. J. G., Froese, D. G., Portnyagin, M. V., Ponomareva, V. V., Garbe-Schönberg, D., and Wennrich, V.: Volcanic ash layers in Lake El'gygytgyn: eight new regionally significant chronostratigraphic markers for western Beringia, Clim. Past Discuss., 9, 5977-6034, doi:10.5194/cpd-9-5977-2013, 2013.
Vogel, H., Meyer-Jacob, C., Melles, M., Brigham-Grette, J., Andreev, A. A., Wennrich, V., Tarasov, P. E., and Rosén, P.: Detailed insight into Arctic climatic variability during MIS 11c at Lake El'gygytgyn, NE Russia, Clim. Past, 9, 1467-1479, doi:10.5194/cp-9-1467-2013, 2013.

Vologina, E., Granin, N., Francus, P., Lomonosova, T., Kalashinkova, I., and Granina, L.: Ice transport of sand-silt material in southern lake Baikal, Russ. Geol. Geophys., 46, 186-192, 2005.

Washington, W. M. and Meehl, G. A.: High-latitude climate change in a global coupled ocean-atmosphere ice model with increasing atmospheric $\mathrm{CO}_{2}$, J. Geophys. Res., 101, 12795-12801, 1996.

Weber, M. E., Tougiannidis, N., Kleineder, M., Bertram, N., Ricken, W., Rolf, C., Reinsch, T., and Antoniadis, P.: Lacustrine sediments document millennial-scale climate variability in northern Greece prior to the onset of the northern hemisphere glaciation, Palaeogeogr. Palaeocl., 291, 360-370, doi:10.1016/j.palaeo.2010.03.007, 2010.

Wennrich, V., Francke, A., Dehnert, A., Juschus, O., Leipe, T., Vogt, C., Brigham-Grette, J., Minyuk, P. S., Melles, M., and El'gygytgyn Science Party: Modern sedimentation patterns in Lake El'gygytgyn, NE Russia, derived from surface sediment and inlet streams samples, Clim. Past, 9, 135-148, doi:10.5194/cp-9-135-2013, 2013a.

Wennrich, V., Minyuk, P. S., Borkhodoev, V. Ya., Francke, A., Ritter, B., Nowaczyk, N., Sauerbrey, M. A., Brigham-Grette, J., and Melles, M.: Pliocene to Pleistocene climate and environmental history of Lake El'gygytgyn, Far East Russian Arctic, based on high-resolution inorganic geochemistry data, Clim. Past Discuss., 9, 5899-5940, doi:10.5194/cpd-9-5899-2013, 2013.

Zech, R., Huang, Y., Zech, M., Tarozo, R., and Zech, W.: High carbon sequestration in Siberian permafrost loess-paleosols during glacials, Clim. Past, 7, 501-509, doi:10.5194/cp-7-501-2011, 2011. 